\title{
Literary Agency in the Wake of Catastrophe The Canonization of the Literary Responses to Trauma
}

\author{
Veronica De Pieri \\ (Università Ca' Foscari Venezia, Italia)
}

\begin{abstract}
Textual agency plays a fundamental role with regard to the literary production devoted to catastrophic events and the trauma they entail; it raises questions about the ethics of the disaster, as if to say the legitimacy of the literary works on the theme. The authorial commitment to bear witness to the events often clashes with the unrepresentability of the event itself: silence and discursivity are both misleading choices in the sense that the first is a real blot on History, while the latter implies to domesticate trauma in order to transpose it into literary forms. This article aims to give relevance to the therapeutic agency of the Literature of the catastrophe and in doing so, it contributes to the re-evaluation of the genre as part of the literary canon.
\end{abstract}

Summary 1. Introduction. - 2 Mimesis and Pleasure as Keywords for the Canonization of the Literature of the Catastrophe. -4 The Textual Agency of the Literature of the Catastrophe. $-4.1 \mathrm{~A}$ Committed Literature . - 4.2 The Therapeutic Value. - 5 Conclusion.

Keywords Literature. Trauma. Catastrophe. Canon. Fukushima.

\section{Introduction}

The definition of agency in the literary field usually refers to the active performance of texts in a restricted socio-cultural domain, that is, in the case of the literary text, the reading target of the literary work in question. This assumption is inspired by the idea that any text, whatever oral, written or iconic, is by no means neutral and it can rather "make a difference" (Cooren 2004, 375). This article aims to show how textual agency is particularly relevant with regard to the literary production known as the Literature of the catastrophe. This label points out the literary responses to a natural or man-made disaster whose catastrophic extent encourages the formation of a collective memory of the historical events; and, at the same time, the genre touches the sensitive subject of individual as well as collective trauma.

The ambitious title of the article revels the urge to reconsider the role of the Literature of the catastrophe - 震災・人災文学 shinsai-jinsai bungaku 
in Japanese - in the light of the increasingly central position that this genre has assumed after the 2011 Japanese Daishinsai. Although this literary production is still marginalized if compared to other popular literary themes, it is precisely its therapeutic quality (read: its agency) to turn it effective as a means to help victims in detecting and working through their trauma. In this perspective, the canonization of this literary genre only takes advantage of the ever-growing popularity of the so-called 3.11文学 3.11 bungaku 'literature of 3.11' in Japan to reassess the function of the Literature of the catastrophe in the broader context of the world literary canon. The author draws off Japanese literary representation of traumatic experiences to develop a theoretical framework of the Literature of the catastrophe in the broadest sense.

The complex process of canon formation is here shortly mentioned in order to provide proof of the legitimate affiliation of the genre to the 'high culture' which encompasses any cultural products of aesthetic value. In doing so, two main keywords are particularly analyzed: mimesis and pleasure. By taking into account the philosophical debate around 'beauty', an overview of the general connotations of the literary classics ascribed to the literary canon is provided; and after introducing its interpretations applied to the literary field, the article underlines the relevance of two different features, mimesis and pleasure, which result particularly significant in the case of the Literature of the catastrophe intended as testimonial accounts.

The article then moves forward to investigate the role of 'agency' and its implications on the literary ground. Special emphasis is given to the definition of the range of the textual agency as it is employed in the Literature of the catastrophe as a genre itself. Above all, to take into consideration the authorial commitment into writing that this particular genre entails is considered crucial as a form of 'literary agency'. At the same time, it is inevitable to investigate the aim that this literary production intends to achieve.

In addition, as textual agency entails not only textual performance in specific settings but also the degree of its action which defines the allocation of its agency (Cooren 2009, 42) the stages of the literary production, mediation and reception should be carefully analyzed too. Hence, it is worthy to underline the importance that the reception of this literary genre showed during the past decades among the literati as well as the wide audience: for example, the literary testimony to Nazi Shoah finds nowadays a loyal public of readers in Western countries and its reading is largely encouraged on a scholastic level for educational purposes. On the contrary the literary production known as 原爆文学 genbaku bungaku 'literature of the atomic bombings' underwent the American censorship soon after WWII, which has greatly contributed to the ghettoization of the genre. Suffice it to say that the first literary testimony about the atomic bombing on Hiroshima, namely 屍の街 Shikabane no machi (City of Corpses, 1948), was drafted by the journalist Ōta Yōko in September 1945 but suffered 
a strict censorial penalization for three years before its first publication. Albeit the Japanese socio-political establishment exhibited a revival of the interests toward hibakusha after the nuclear accident at the Fukushima Daiichi Nuclear power plant, this literary production is a long way from obtaining the evaluation it deserves as a therapeutic literary production.

In the case of the Literature of the catastrophe the target to which the literary product is addressed as well as the broader audience involved in the reading are fundamental factors to be considered in order to shed light on how the textual agency of the genre is fully performed. Actually, the literary texts prove to be effective on two different levels - writing and reading - which both encompass the peculiar therapeutic value that the testimony accounts accomplish. This is seen as an important added value of the literary genre in question, as well as the heart of its 'agency', totally performed through the psychotherapeutic process of the "abreactive catharsis" and the "catharsis of integration" (Dayton 2000, 96), deeply described later.

By stressing the relevance of mimesis and pleasure as fundamental characteristics at the basis of the canonical literary works and by giving a new interpretation of the Literature of the catastrophe's agency according to the commitment of the testimonial literature and its therapeutic potential, this article aspires to contribute to the re-valorization of the genre and, in doing so, to prove its legitimate membership in the literary canon.

\section{Mimesis and Pleasure as Keywords for the Canonization of the Literature of the Catastrophe}

It should be noticed that the Literature of the catastrophe owes several characteristics that the long philosophical debate around the canon formation has brought to light as fundamental for the aesthetic evaluation of the artwork. To talk about literary canon nowadays may seem pointless to some extent, unless there is the intention, as this is the case, to give a stronger voice to the therapeutic power of the genre. Walter Benjamin was perhaps the first to diagnose "der Verfall der Aura" ([1935] 1989, 17) in our era, as to say the downfall of the value of the artistic work, today mostly mass-manufactured. John Whittier Treat echoed this analysis by defining the Japanese literary production by contemporary authors like Yoshimoto Banana and Murakami Haruki as 使い捨て tsukaisute that is, "reading and throw away" literature (Treat 1993, 357). The label clearly refers to free-flowing readings well suitable for entertainment but often forgotten after their fruition. For the record, Ōe Kenzaburō's Nobel Prize acceptance speech in 1994 mirrored Treat's consideration by labelling the above-mentioned Yoshimoto and Murakami as "subculture writers", a criticism shared also by Etō Jun (McKnight 2011, 205-6). It results the devalu- 
ation of the trendy literature that since the dawn of twentieth century was defined in Japan as popular - 大衆文学 taishū bungaku 'popular literature'; this term was commonly accepted by the literary establishment in order to distinguish it from the 純文学 jun bungaku 'high literature', the literary production focused on more elevated themes (Suzuki 2000). Notwithstanding, this is the appellation used by Japanese writers like Abe Kazushige and Kawakami Mieko among others, to define their literary productions after 11 March 2011 - see, for example, the literary cross-talks published by Waseda Bungaku (2012). This authorial declaration is anything but irrelevant if interpreted as a statement of quality assurance of authorial works, perceived as 'high' literary production although devoted to the three-fold catastrophe of earthquake, tsunamis and nuclear meltdown. Nevertheless, the 3.11 bungaku still remains appanage of a small élite of critics who are interested in the investigation of the intricate relationship among literature, trauma and catastrophe; and the big success among the audience is likely to emphasize the empathy of Japanese people towards Tohoku victims.

Of course, the jun bungaku/taishū bungaku debate cannot be dismissed in a few lines and should deserve further investigations; right now I limit my considerations to the self-assessment expressed by Japanese authors in evaluating their testimonial products. It should also be acknowledged how the distinction between the two labels is restricted to Japanese literary production and does not affect world-wide literature, according to Britannica Encyclopaedia 2013: "nowadays the examples of the worldwide taishū bungaku are detective novels and science fiction." [Authors' italics, Japanese in the original], (Nakamura 2014, 25)

Back to the canon formation issue, some considerations can be drawn up by underlining the importance of mimesis to aesthetically evaluate a product of art. Aristotle defined it in his Poetics (trans. Butcher 1902) as the perfect imitation of reality. The mimesis concept found large consensus among the representatives of the French Naturalism movement and it witnessed its Japanese interpretations almost a century later, in the twenty-first century, through the works by Natsume Sōseki and Mori Ōgai, among others. Furthermore, Japan saw the birth of the treatise on the topic of the modern novel by Tsubouchi Shōyō: his 小説神髄 Shōsetsu shinzui (The Essence of the Novel, 1885) well summarized the relevance of mimesis (模写 mosha) in the representation of human feelings (人情 ninjō) briefly indicated by seven different emotions (喜怒愛楽 kidoairaku) developed in a specific environment - Zola's milieu became Tsubouchi's 世態 setai (Bienati, Scrolavezza 2009, 30-3).

The central role of mimesis is recognized by the Literature of the catastrophe too, especially with a reference to testimonial accounts and documentary novels: the reliability of the work is extremely important to the victims in order to be truthful to their experiences. To prevent any artistic 
(read: literary) manipulation of the historical events means to protect the memory of I sommersi $e$ i salvati (The Drowned and the Saved) to borrow Primo Levi's words, who was one of the authors who considered the writing about Nazi's deportation a moral commitment for the survivors as much as for the broader public. The author also refused any form of fictionalized work on the ground that "the theme of the massacre is not open to revision and fiction. The few novels written on the topic are odious, they are disgusting to read" (Levi quoted by Sullam 2010, 108) According to Levi, any efforts in conveying the traumatic experience into literary forms is acceptable as long as it enables the reader to sympathize with the victims. The lyricism attributed to his works by the critics suggests the attempt to transpose the traumatic experience into words - see for example the outstanding metaphor between Auschwitz's life and Dante's Inferno (Levi 1958) - but the verbalization of the atrocity does not corrupt the experience itself, neither it tries to domesticate the catastrophe. To aesthetically portrait the disaster does not equal to beautify it in a strict sense but it means only to create a new literary language able to convey the nightmarish, barbaric and shocking experience, if possible.

By stating that mimesis is one important attribute of the Literature of the catastrophe, it might seem that all the fictionalized literary works on the theme are excluded from the evaluation of the genre. Actually, the semantic proximity of the term fictio to inventio, which are both translatable as 'shape with fantasy', is the source for the allusion to the linguistic and literary creativity, hence the adjectives 'fictional' and 'fake, false' with their negative connotations (Segre 1985, 214). This, then, fomented the debate between Plato and Aristotle regarding 'art as a lie' or 'art as a keeper of truth': the first assertion focuses on fictio in its most negative sense while the other interprets any manifestations of art like a mimesis of reality (215). Actually, hybrid production can be detected too, in a progressive passage from mimesis to verisimilitude to fiction.

Anyway, it should also be remarked that according to the re-definition of the Aristotle's term by French and Japanese Naturalism, any form of imaginary portrayals of real life well suit the terminology - see, for example, Tsubouchi Shōyō's Shōsetsu shinzui mentioned earlier. In this sense Levi's averse attitude towards Shoah fiction as well as Adorno's statement about the impossibility to write poetry after Auschwitz $(1955,30)$ appear only like exceptional cases of extremely hostile stance of the authors towards fictionality. This is what is commonly addressed to as the debate of the 'ethics of the disaster', in other words the legitimacy of any artistic or literary discourse on the theme, since the catastrophe calls into question the aesthetization of the dehumanization, as well as catastrophe's (un)representability, especially when it deals with the critical trauma of loss, abandon, death.

More complex is the attribution of pleasure, which came to the fore in the second half of twenty-first century thanks to the Decadent movement. 
Oscar Wilde, the Italian D'Annunzio and his Japanese counterpart, Mishima Yukio, are examples of literary hedonists who embraced Théophile Gautier's slogan "l'art pour l'art” (1835). This vision of the artistic field highly influenced the production of authors like Roland Barthes who, almost one century later, defined the literary work by the French terms plaisir or jouissance, 'pleasure', 'amusement' (1982, 29); the literary text became a concrete, almost erotic body: a source for pleasure which is an end in itself.

But how to apply the attribute of pleasant to literary works on a catastrophic and traumatic subject? Assuming that this operation is not a forced artifice simply intended to underline the aesthetic value of this literary production, history comes in help: Voltaire's (1759) (Gargantini 2005) Candide, ou l'Optimisme (Candide: Optimism) and Kamo no Chōmei's ([1212] 2011) 方丈記 Hōjōki (An Account of My Hut), only to mention a few, are considered everlasting classics, fundamental in the construction of the literary canon of France and Japan, respectively. Hence, is it possible that a literary work on great environmental upheavals which overwhelm the miserable protagonists assumes the connotation of pleasant?

Kant (1790), in his Kritik der Unteilskraft (Critique of Judgment) pointed out how the aesthetic judgment can be interpreted according to the reference of 'beauty' (as opposed to the sublime), and even more specifically, judgments about the beauty of nature (as opposed to art). The concept of sublime is taken into consideration in the sense of what is immeasurable; a contradictory feeling of attraction and repulsion that emerges from the confrontation with natural forces (Kant 1790, 250). The human being perceives a profound discomfort due to his conscious inadequacy - defined as 'Das mathematisch Erhabene' (mathematically sublime, 260) - and the disarming physical impotence to face nature itself - called 'Das dynamischErhabene' (dynamically sublime, 260). Any natural manifestation is perceived by Kantian philosophy with extreme astonishment and amazement, thus evaluating its aesthetic perception of 'incredibly fascinating':

The sublime is a key moment [...] so overwhelming as to defy reason to understand. It is a moment 'beyond representation'. Sublimity is the means by which the presentation (Darstellung) of the trace of the event [...] is accomplished by a failure inherent in representation (Vorstellung). The sublime, Kant claims, involves negative presentation, an experience of the breakdown of the accord between the imagination and the understanding [Authors' italics]. (Bernard-Donals, Glejzer 2001, 13)

Because of the extraordinary nature of the event, it goes beyond representation, hence the failure in any adequate testimony. The judgment of the sublime takes action only when the patient is overwhelmed by the agent in a way that can even lead to his apocalyptic annihilation. 
It is undeniable that tsunamis, volcanic eruptions, earthquakes have been subject of fascination since the dawn of time. Their study is not merely cautious: the thinly disguised concern reveals the attractive power of these events on human beings. Since any kind of natural or man-made 'catastrophe' is the main theme of the literary genre in question, the attraction these works has on the wide public is easily explained. Moreover, readers not only share the interest in extraordinary events beyond the reach of human's power, but they also demonstrate the urge to learn about those tragic accidents to prevent them to happen again in the future. Furthermore, the public can also enjoy the beneficial effects this reading provides in the form of witness' testimony at least in two different forms: recording data and therapeutic means to overcome trauma (this point will be developed later).

Even though the Literature of the catastrophe shows the compliance to mimesis and pleasure concepts for natural forces which confirms the value of timeless classics like Candide and Hōjōki, the literature of the genre does not find wider deployment on contemporary bookshelves in the sense that it seems not as much appreciated as other literary genres. Of course, it is a committed literature which refuses to be read only for fun. It is not by chance that, as noticed before, the so-called 'Shoah Literature' finds in Western countries widespread use in schools for educational purposes. בשואה As a matter of interest, it is worthy to mention that the Hebrew term shoah finds its translation in the English 'catastrophe'; on the contrary abominable is the undignified label 'Holocaust narrative' due to the implicit meaning of sacrifice that the label 'holocaust' entails.

What is clear from this last consideration, is that the art (read: literature)'s purpose needs to be taken into account too, in order to consider with foresight the role of the Literature of the catastrophe in the broader literary canon.

\section{The textual agency of the Literature of the catastrophe}

\subsection{A committed literature}

To speak about the qualities of the classics which are objects of the process of the literary canonization implies of course to talk about originality, creativity, uniqueness - as underlined, among others, by the concept of 'genius' in Schopenhauer (1844). It goes without saying that mimesis and pleasure do not suffice to determine the status of the literary works in question. In this sense, useful is the analysis proposed by the critic Harold Bloom (1994) in his The Western Canon. Bloom conceived the canonical standard as a "conflict between past genius and present aspiration in which the prize is literary survival or canonical inclusion" (8) and, by describing the 
works by William Shakespeare - the centre of Western canon in Bloom's perspective - the author elaborates further considerations on the aesthetic value of literature, inter alia:

1. cognitive acuity (associated with a great ability to understand and transpose into literature human psychology and its mutability);

2. linguistic energy (in terms of will to figuration and motive for metaphor); and

3. power of invention, considered as the competence to mirror reality (mimesis) as well as the quality of being inventive. (9)

This scheme works as a recapitulation of the necessary features that qualify the literary classics and that are also shared by - at least - the majority of the literary texts which belong to the Literature of the catastrophe. A Japanese counterpart to this scheme can be found in Nakamura's essay and his considerations about "the salt of the earth" and "the light of the world" which led the critic to underline the qualities of "great kindness, reliability, or honesty" and "conspicuous for virtue, intellect [...] a luminary." (Nakamura 2014, 27) It is worthy to stress that this analysis was deeply influenced by Western approach to aesthetics. Notwithstanding, I would like now to move forward to a related topic, the one of art (read: literature)'s purpose which is equally significant if considered the sensitive themes of the genre.

Actually, having settled the issue of the 'agency', it is extremely relevant to notice how the term also entails "la capacità umana di agire" 'human capacity of action' (Ahearn 2002,18). This general definition refers to human activities and performances and requires to be embedded in the narrower field of the literary text in order to fulfil the main topic of this article. The textual agency, as to say, the ability of the text to create theory of action (Derrida 1990,13), genuinely disguises authorial commitment into writing as well as the purpose of his literary work.

A first observation should be addressed to the terminology to indicate literature's function or intention - Zweck as reported by Kant's writings, not to confuse with Zweckmäßigkeit translatable as 'purposiveness': according to this nomenclature the 'beauty' does not have to be useful but there must be a particular reason under its existence $(1790,146)$. It goes without saying that this interpretation clashes with the consideration of art (read: literature) as a pure entertainment; the debate around the tsukaisute production - books as mere consumer goods - comes to the fore again. Actually, if we take for granted that any single artwork owes a value because it is the result of human's creativity and talent, it is difficult to downgrade any literary work. It is not by chance that the intent of the artistic production is taken into account: it makes the difference between two literary products - A and B - both created with authorial originality but which show the different aims of amusing (A) or informing (B) the public. 
Following this approach, I would like to turn the attention to the meaning attributed to the quality of inutile 'useless' by Sartre ([1948] 2008, 88), who saw the literary production as the result of a free creative act in terms of liberté/gratuité 'liberty/gratuity', a combo the critic often discussed. According to this viewpoint, the value of the literary product is inestimable: it is actually impossible to estimate the fruit of human's intellectual efforts. And, only in this perspective, the aspiration to an ultimate creation avoids ethics and morality to find the perfection in the futile and pointless art. It is interesting to underline how Sartre's considerations ascribe a positive attribute to the inutile linked to any artworks. The logic of profit that rules human society's mindset nowadays is antithetical to this concept: anything useless usually looses its sense of existence. Following this approach, Japanese literati frequently debated regarding the distressful impotence of literature after 3.11 disaster. Among others, Takahashi Genichirō's literary productions testify an interest towards the role and use of language in the wake of catastrophe - see his「あの日」から僕が考えている「正しさ」について 'Ano hi' kara boku ga kangateiru 'tadashisa' ni tsuite (About the 'Correctness' I Have Thought since 'that Moment', 2011) and 非常時の言葉 Hijōji no kotoba (Words of Emergency 2012). In a crosstalk with Sasaki Azushi and Abe Kazushige, the latter stressed the fruitless stance of literature arguing that the 3.11 underlined exactly the weakness in literary production: "When I thought about what literature could do [after 11 March] I am afraid to say anything came out to me. It is useless to the extent I was shocked" (Abe, Sasaki, Takahashi 2015, 27). Again, the novelist echoed himself in the 言葉もまた壊された Kotoba mo mata kowasareta (Even words crushed once again, 2016) interview by the Asahi Shinbun: "the trust in words incredibly faded. [...] Wherein, it is necessary to restore the value of words one more time". And actually, the cross-talk with Takahashi and Sasaki concludes with Abe stressing the real role of literature, in his own opinion: to cool down the crazy and reflect to what can be done to recover Japan's devastated areas and help its refugees with a clear head (Abe, Sasaki, Takahashi 2015, 28).

Likewise, the lay impératif moral 'moral imperative' proposed by Sartre ([1946] 1998) in his La responsabilité de l'écrivain (The Responsibility of the Writer) and throughout his collection of essays reveals the perception that morality is a part of authorial engagément 'commitment'. According to this theory "la réalisation plénière de la liberté" 'plenary realisation of the liberty' (Benoît 2000, 33) of the author consists in assuming all the consequences that the act of writing entails. Authorial engagement into writing, and implicitly, the purpose which pushes him to write, are to be considered as the double faces of the same 'agency' coin: the starting engine of the process of writing which assumes a particular connotation in the case of the Literature of the catastrophe: 
by focusing on textual performance, we challenge our overreliance on face-to-face interaction and show that texts contribute to the local translocation of constraints and abilities. (Cooren 2004, 374)

This aspect is actually extremely topical and relevant when dealing with any literary response to a traumatic event. The keyword here, as underlined by Kobayashi in dealing with Japanese post-3.11 literature, is exactly the common matrix that "response" and "responsibility" share: "It must not be forgotten that in case there is the chance to carry out a 応答 outou 'response' to face others' inquiry, there, 責任 sekinin 'responsibility' follows" $(2012,4)$. What moves author's pen is a clear moral imperative towards his audience as well as towards the literary (read: testimonial) work itself. The compelling plea to participate in the socio-political debate in the wake of catastrophe also involves the individual (read: authorial) integrity that the process of writing and witness encompass. In this sense the Literature of the catastrophe responds to the Sartrean perspective of a littérature engagée 'committed literature' which implies a total commitment of the author in the writing (Sartre [1946] 1998).

Of course, this idea is extremely controversial on two fronts. First, because it implicitly bans from the canon all the literary works that answer to the only demand for plaisir or juissance, as mentioned earlier by taking into consideration the pure entertainment feeling engendered by the Trivialliteratur, as to say the trivial or commercial literary production for leisure - before labelled by the Japanese term tsukaisute. However, this problem does not concern the Literature of the catastrophe, as already analysed before. Second, observing the requirements in order to be considered as 'committed literature', implicitly means to argue again the legitimacy of intervening into the memories of the historical events in order to aesthetically portrait the catastrophe. The ethical debate around disaster's representability is always on the prowl and has to be taken into account every time we approach a literary work on the theme:

The sublime moment is that in which the witness knows that she is seeing but can't say what it is, and yet must say what it is. (Bernard-Donals, Glejzer 2001, 20)

It is now time to turn to the therapeutic value of the Literature of the catastrophe. 


\subsection{The therapeutic value}

It is necessary to put emphasis on how this literary production, often devaluated by the literary establishment and marginalized, presents a significant added value which is able to rehabilitate the genre. And it is also the lieu where its textual agency is better performed, namely the therapeutic potential that this production fosters for the victims.

As concerns Japanese literature, the attribute of 'healing' is not anew: the label of 'healing narrative' - 癒 L iyashi in Japanese, translated as 'comfort and healing' by Gebhardt $(2004,257)$ refers to a literary trend born in the late 1990s to respond to the new popular culture of New Age, Yoga and Asiatic medicine boom (262) The concept of healing in literature is easily summarized in a therapeutic narrative which aims to cure readers' wounds and trauma by suggesting new ways to approach pain and suffering in daily life. The novels by Yoshimoto Banana are emblematic examples of this literary production, which actually cannot be addressed as a 'testimonial literature' in a strict sense: indeed, these literary works are not based on historical facts that claim for social awareness but rather on fictional portraits of troubled characters looking for the reconstruction of their microcosm in the everyday life, often supporting a review of social behaviour and morality.

Otherwise, the Literature of the catastrophe which is at the core of this study is strictly connected to witness' testimony and its therapeutical value is taken into consideration as far as the writing/reading can benefit both author/reader, whatever victims or non-victims.

The agency is expressed all-round: the therapeutic value of the literary product is articulated during the writing process as well as during the act of reading. Therapeutic is the gestation's phase of the literary product as far as it provides the author with the possibility to work out the trauma actively; and therapeutic is the literary product itself thanks to the curative effects that its reading can stimulate in the audience. The writing process is experienced by the author as a sort of "confessional literature" (LaCapra 2001, 8) for which the writing itself represents a scriptotherapic exercise - the latin matrix scripto underlined the means of the therapeutic act - to work out his own trauma in the case of a first-person account. The 'working out' is perceived by LaCapra as the "acting (or playing) out in performative discourse or artistic practice" (186) and it is at the basis of any literary productions which belong to what he called "traumatic and post-traumatic writing" (186).

The reading can be effective because, in the case of the testimonial literature, the literary product aims to become the locus of a therapeutic session between author/therapist and reader/patient (Shimokōbe 2006, 23). This mechanism is deeply analysed by Tian Dayton (2000) who identified two preparatory phases in the therapeutic session: the "abreactive catharsis" 
(295) which derives from the Freudian Abreagieren 'abreaction' and which consists in the regression of the victim to a past event, often repressed - a sort of "historical retroaction" (Laub 1995, 70) - and its oral or written articulation. The second stage is represented by the "catharsis of integration" (Dayton 2000, 296), as to say the achieved capacity of the victim to recognize and verbalize his emotions. The first reaction of victims to trauma is indeed a form of emotional illiteracy which is scientifically called 'alexithymia' and

refers to a condition in which people have no words to describe their emotional states, either because they have no awareness of their inner states or because they cannot distinguish one emotion from another. (102)

This particular condition can often be accompanied by a form of anhedonia - a lack of pleasure or of the capacity to experience it - or analgesia - the absence of sense of pain (Krystal 1995, 29) - which both contribute to the temporal stasis of the victim. Hence, the phase of the catharsis of integration aims to develop the awareness of the patient who can give a start to the healing process from trauma. This process can be performed through re-enactment - in the case that the figures of reader and victim match - or through transference - with regard to a no-victim reader. What remains essential is the verbalization and articulation of victim's experience through any communicational forms able to be decoded and interpreted by the receiver.

To sum up, the textual agency of writing and reading about catastrophe (read: trauma) transforms the literary work into the meeting point where the abreactive catharsis and the catharsis of integration are performed according to a double-edged action on the writer and on the reader.

In literary terms the abreactive catharsis can take the shape of a private account: mémoire, diaries, private memos are the most frequent forms of this intimate literature which provides a highly therapeutic benefit. Actually the psychotraumatologic term 'scriptotheraphy' denotes the various forms of writing used for therapeutic purposes, for which the journaling - Barthes' ([1966] 1999, 54) journal intime (private journal) - is the prevailing form. Indeed, this practice is highly used in counselling session and cognitive therapy - a psychotherapy treatment based on the assumption that things can affect people emotionally.

On the grounds that this literary authoring is usually highly influenced by the subjectivity (read: emotionalism) of the author, it is obviously not a reliable production from an historical point of view but it can offer a testimony of the events as perceived by the victims themselves. LaCapra, again, pointed out the risk a "faux mémoire" 'false diary' $(2001,18)$ can entail, considering aporias, paradox, impasse, hyperbole as a failure for the realistic representation of the historical event thus compromising not only the compliance to the historical facts but also the possibility of mourn- 
ing in the sense that absence, loss, silence prejudice the testimony itself. The boundary between the need for an historical archive and for a true testimony of the experience is a fine line that seems to find no answer yet: to report the historical facts means to ignore the human element while to bring justice to the whole experience of the victims implies to accept a poetic license able to sensitize the audience and to convey an emphatic feeling into the testimonial writing.

Notwithstanding, the fidelity to the fact is more detachable in journalistic inquiries, reportage, scientific study on the catastrophe: this nonfictional production is more reliable than the fictionalized work in order to provide a meticulous historical recording.

The so-called 記録文学 kiroku bungaku (documentary literature) finds in Japanese literary production an old tradition: the above-mentioned Hojjōki constitutes only a first, great example of catastrophe-related literary recordings. Despite the large number of works on the topic of earthquake and tsunamis - among which the testimonies of the Great Kantō earthquake (1923), and the most recent Great Hanshin earthquake (also known simply as Kobe earthquake, 1995), the Tohoku earthquake (2011) and the Kumamoto earthquake (2016) are worth mentioning - the legacy of the genbaku bungaku plays a fundamental role in the constitution of a repository of Japanese testimonial literature.

At this point, I have only marginally touched the theme of memory when talking about the faux mémoire. Actually, although the imperative to bear testimony - Shoshana Felman's appel à téimogner 'call to testimony' (1995, 16) - implies the loyalty to the memories, it must be underlined how the truth of the historical facts and the true memories of the experience as perceived by the victims might not match at all. Thus, the case of the faux mémoire mentioned by LaCapra for which the memory of the events are corrupted in order to protect one shattered self. Moreover, another reason which can transform witness' testimony in a faux mémoire can be found in the intentional or unconscious need for victimization, which can involve both author and audience. The victimology study actually reveals this is the side effect of the textual agency of the Literature of the catastrophe in the sense that the literary work becomes the proof of author and reader's sufferance, thus convincing - sometimes - both part of their own martyrdom.

The role of memory in the testimonial account should not be underestimated, neither; the following example by Cooren (2004) can shed a light on the relationship between textual agency and memory. Talking about a manager who left notes in his office Cooren explained:

One interpretation of this practice is that these notes reminded the manager what needed to be done. Another possible read, as speech act theorists would claim, is that the manager performed the act of reminding himself. (378) 
Thus, in the case of the Literature of the catastrophe, the text (read: testimony) represents the material (read: actual, psychical) memory of the event; its textual agency is then achieved through the writing - the author/witness reminds to himself what happened - as well as through the reading - the author/witness reminds to the audience what happened. In this sense the textual agency can be interpreted as an imaginary process of re-enactment/transference of the event (see above) or a perpetual, immortal memory of the experience as long as the reading of the testimonial narrative is accomplished. Ergo, the relevance of the Literature of the catastrophe as everlasting (read: perpetual, immortal) classics.

Further considerations deal with the role of the author as the witness of the experience. Generally speaking it is common to acknowledge as a first-hand witness the person who directly experienced the historical event; different is the case of a mere conosseurs de facts (Hayden White's 'middle voice'; LaCapra 2001, 25), someone who assisted to the events although not being directly involved in the situation. A simple example of the present day is enacted by what I defined elsewhere 'media witness' (2018) for whom the traumatic experience is 'mediated' by video footage on the web, TV news, live cams and who are likely to act pushed off sociopolitical reasons. Of course, there might be also cases in which the catastrophe appears as a main theme of the literary production of authors who are totally unfamiliar with the incident for whom they show a particular interest. Nevertheless, the status of the writer is unlikely to interfere with the textual agency of the literary product in question, unless its potential is not plentifully performed by the working out and through the trauma that the catastrophe entails.

Among Japanese authors, the response to the popular plea to come into action and speak on behalf of the victims is extremely resounding. The Nobel Prize winner Ōe Kenzaburō stood up for encouraging the anti-nuclear movement during the さようなら原発 Sayounara genpatsu demonstration on 19 September 2011 but this action was not isolated: in addition to his History Repeats article on The New Yorker (2011), it should be remembered his commitment devoted to Hiroshima's victims - see his ヒロシマ・ノート Hiroshima nōto (Hiroshima notes, 1965) and 何とも知れない未来に Nantomo shirenai mirai ni (usually translated in "The Crazy Iris and Other Stories of the Atomic Aftermath', 1983) for instance. But the list could be longer: Tawada Yōko, Wagō Ryōichi, even Murakami Haruki took actively part in bearing the testimony of 11 March victims, by paying homage both personally and through their literature.

According to a strict literary point of view, the authorial commitment can be manifested frequently during author's literary career or can be shown up only as a cameo in his production. It also appears clearly how the literary transposition of the traumatic experience, especially in the case of first-hand witness, requires time to be working through, thus constitut- 
ing a long-distance literary production. Otherwise, following the urge of bearing testimony, the witness can give birth to a prolific literary career based mainly on his traumatic experience; this production is usually addressed to as 'literature of the debris' from the German Trümmerliteratur (Tachibana 1998, 7) a term used to describe the first literary responses of German authors to WWII and Nazi's behaviour at the concentration camps. Anyway, the textual agency of the 'literature of the catastrophe' maintains unchanged its healing potential since the psychotherapeutic abreactive catharsis and catharsis of integration are performed at the core of the literary product. In a sense, it demonstrates how the author and his work "can act from a distance across space and time" (Cooren 2004, 380).

\section{Conclusion}

The Literature of the catastrophe demonstrated to be a fully-fledged part of the complex world of the literary canon: the fidelity to the factual reality (mimesis) is underlined by the testimonial accounts while the interest in the astonishing natural power testifies the pleasure it produces (sublime). Moreover, this genre, by its very nature to constitute a testimonial archive of historical facts of particular atrocity, is likely to survive the literary trends, thus raising its status from fashionable but flimsy works to everlasting ones - the 'high' literature that finds its Japanese translation in jun bungaku.

Foremost, this study focused the attention on the double faces that textual agency manifests in the Literature of the catastrophe. Indeed, the article considered the textual agency not according to its semantic perspective, as it is usually the case (Ahearn 2002, 22), but in a broader sense.

First, the moral commitment of the author was taken into account in order to evaluate the genre as a 'committed literature' - Sartre's littérature engagée - which not only demands for a re-consideration of the intrinsic value of the genre but alsos represents a way in which its textual agency is performed. The 'committed literature' actually acts into the reading to catalyze audience's attention on sensitive socio-political issues, which become the main topic of discussion in the case of the Literature of the catastrophe in the forms of trauma, wound, suffering, mourning. In this particular sense the literary text represents also the literary venue where the trauma is acting out and worked through, if possible. The psychotraumatologic studies applied to the literary field then reveal to which extent testimonial narrative can be effective in the healing process of trauma.

This is the peculiar agency of the Literature of the catastrophe, underlined by its therapeutic value. The article tried to illustrate how the textual agency works in the Literature of the catastrophe in a very practical sense by enacting the process of the abreactive catharsis and the catharsis of 
integration, involving both author and audience. It is extremely relevant that Cooren himself recognized in the definition of 'agency' the "capacity of (oral, gestural, and written) texts to do things (in the most literal sense of these terms)" $(2009,58)$ The Literature of the catastrophe represents in this perspective and emblematic example of concrete, pragmatic textual agency whose benefits are recognizable in both author/witness and reader. The testimonial works become "textual agents" (Cooren 2009, 61) whose influence on the audience is beyond dispute.

In addition, by considering 'agency' as a synonym of action, Cooren made it clear that "an action then is a transformation of state operated by an agent" (2004, 376) This is exactly what happens with the agency of the Literature of the catastrophe since the therapeutic effect (read: action) over the writer as well over the readers is also fuelled by the moral commitment that the testimonial writing entails, thus enhancing the potential agency of the genre.

All in all, by focusing on the moral commitment of the author and on the therapeutic benefit of both the acts of writing and reading, this article tried to illustrate how the therapeutic power of this literary genre, namely, its agency, is developed throughout the process of its writing (read: production) as well as reading (read: reception).

Of course, this article does not pretend to be conclusive but it rather would like to represent the starting point of a wider investigation on the topic. The multidisciplinarity of the discourse was highlighted in the article: literature, philosophy, anthropology, psychology, all are subjects involved in determining the value of the Literature of the catastrophe. A literary genre which responds to the exhortation of History to tell itself; to the moral imperative to bear testimony; to victims' auto-determination to break the silence and articulate their trauma, which, precisely thanks to literature, can perhaps be exorcised and healed.

\section{Bibliography}

Abe Kazushige, Sasaki Azushi, Takahashi Genichirō (2015). 社会と文学 一20年と震災後の小説たち “Shakai to bungaku. 20 nen to shinsaigo no shōsetsutachi" (Society and Literature. 20 Years and Post-disaster Novels). 小説トリッパーShōsetsu Tripper (Tripper Novel). Tōkyō: Asahi Shinbun Shuppan, 6-28.

Abe Kazushige (2016). 言葉もまた壊された 作家・阿部和重さん 東日本大震災1年

"Kotoba mo mata kowasareta Sakka- Abe Kazushige san Higashi Nihon Daishinsai ichinen" (Even Words Crushed once again. Novelist Abe Kazushige. One Year from the Great East Japan Earthquake). 朝日新聞 Asahi Shinbun. Tōkyō: Asahi Shinbun Shuppan, 13. 
Adorno, Theodor (1955). Prismen. Kulturkritik und Gesellschaft. Berlin: Suhrkamp Verlag.

Ahearn, Laura M. (2002). “Agentività / Agency”. Duranti, Alessandro (ed.), Culture e discorso. Un lessico per le scienze umane. Roma: Meltemi, 18-23.

Butcher, S.H. (transl.) (1902). The Poetics of Aristotle. With Critical Notes and Translation. London: Mc Millian \& Co.

Barthes, Roland [1973] (1982). Le plaisir du texte. Paris: Points Essais.

Barthes, Roland [1966] (1999). Critiques et Vérité. Paris: Éditions du Seuil.

Benjamin, Walter [1935] (1989). Das Kunstwerk im Zeitalter seiner technischen Reproduzierbarkeit. Frankfurt am Main: Reclam.

Benoît, Denis (2000). Littérature et engagement. Paris: Éditions du Seuil. Bernard-Donals, Michael; Glejzer, Richard (2001). Between Witness and Testimony. The Holocaust and the Limits of Representation. New York: State University Press.

Bienati, Luisa; Scrolavezza, Paola (2009). La narrativa giapponese moderna e contemporanea. Venezia: Marsilio.

Bloom, Harold (1994). The Western Canon: The Books and School of the Ages. New York: Harcourt Brace.

Caruth, Cathy (1995). Trauma. Explorations in Memory. Baltimore: Johns Hopkins University Press.

Cooren, François (2004). “Textual Agency: How Texts Do Things in Organizational Settings". Organization, 11(3), 337-93.

Cooren, François (2009). "The Haunting Question of Textual Agency: Derrida and Garfinkel on Iterability and Eventfulness". Research on Language \& Social Interaction, 42(1), 42-67.

Dayton, Tian (2000). Trauma and Addiction. Ending the Cycle of Pain through Emotional Literacy. Florida: Health Communications Inc. Publishing.

De Pieri, Veronica (2018). Fukushima testimonies [PhD dissertation]. Venice: Ca' Foscari University.

Derrida, Jacques (1990). Limited Inc. Paris: Galilée.

Eco, Umberto (2002). Sulla letteratura. Milano: Bompiani.

Felman, Shoshana (1995). "Educational Crises of the Vicissitudes of Teaching". Caruth 1995, 13-60.

Gargantin, Stella (2005). Voltaire: Candido o l'Ottimismo. Milano: Feltrinelli. Trans. of: Candide ou l'optimisme. Paris: Sirène, 1759.

Gebhardt, Lisette (2004). “Der Konsum von 'Heilung' (iyashi) in der japanischen Gegenwartskultur und die Remigio-Reise nach Asien”. Gelebte Religionen. Untersuchungen zur sozialen Gestaltungskraft religiöser Vorstellungen und Praktiken in Geschichte und Gegenwart. Würzburg: Verlag Königshausen \& NeumannGmbH, 325-38.

Kamo no Chōmei [1212] (2011). 方丈記 Hōjōki (An Account of My Hut or The Ten Foot Square Hut). Ed. Sokyū Gen'yū, 無常という力一「方丈記」に学 
ぶ心の在り方. Mujō to iu chikara. 'Hōjōki' ni manabu kokoro no arikata. Tōkyō: Shinchōsha

Kant, Immanuel (1790). Kritik der Unteilskraft [online]. URL http://gutenberg.spiegel.de/buch/kritik-der-urteilskraft-3507/1 (2017-05-30).

Kobayashi Masahiro (2012). 3.11 の応答、への応答 3.11 he no outou, he no outou (The Response to 3.11, the response). A Labo no. 02. URL https://wWw.iamas.ac.jp/labo/a/Res0426MaedaD_files/alabo20120329. pdf (2018-10-10).

Kristal, Henry (1995). “Trauma and Aging: A Thirty-year Follow-up”. Caruth 1995.

LaCapra, Dominick (2001). Writing History, Writing Trauma. Baltimore: The Johns Hopkins University Press.

Laub, Dori (1995). "Truth and Testimony: the Process and the Struggle". Caruth 1995, 61-75.

Levi, Primo (1958). Se questo è un uomo. Torino: Einaudi.

McKnight, Anne (2011). Nakagami, Japan: Buraku and the Writing of Ethnicity. Chicago: University Of Minnesota Press.

Nakamura Takeshi (2014). 文学の役割 Bungaku no yakuwari (The Role of Literature). Tōkyō: Showa Women's University Press.

Ōe Kenzaburō (1965). ヒロシマ•ノート Hiroshima nōto (Hiroshima Notes). Tōkyō: Watanabe Shoten.

Ōe Kenzaburō (1983). 何とも知れない未来に Nantomo shirenai mirai ni (The Crazy Iris and Other Stories of the Atomic Aftermath). Tōkyō: Shoeisha.

Ōe, Kenzaburō (2011). "History Repeats" [online]. The New Yorker, 28 March. URL https://www. newyorker.com/magazine/2011/03/28/history-repeats (2011-10-12).

Ōta Yōkō (1948). 屍の街 Shikabane no machi (City of Corpses). Tōkyō: Chūōkōronsha.

Sartre, Jean-Paul [1946] (1998). La responsabilité de l'écrivain. Conférence donnée à l'UNESCO en 1946. Paris: Verdier.

Sartre, Jean-Paul [1948] (2008). Qu'est-ce que la littérature? Paris: Gallimard.

Shimokōbe Michiko (2006). トラウマの声を聞く。共同体の記憶と歴史の未来 Trauma no koe wo kiku. Kyōdōtai no kioku to rekishi no mirai (Listen to the Voice of Trauma. Common Rememberings and Future's History). Tōkyō: Misuzu Shobō.

Waseda Bungakukai (ed.) (2012). 震災とフィクションの距離 Shinsai to fikushon no 'kyori' (The Relation between Disaster and Fiction). Tōkyō: Waseda bungakukai.

Sullam, Simon Levis (2010). "Elie Wiesel e Primo Levi, memorie divise di Auschwitz". Comunità Ebraica di Venezia (ed.), Oltre la Notte. Memoria della Shoah e diritti umani. In occasione degli 80 anni di Elie Wiesel. Firenze: Giuntina. 
Segre, Cesare (1985). Avviamento all'analisi del testo letterario. Torino: Einaudi.

Schopenhauer, Arthur (1844). Die Welt als Wille und Vorstellung. Leipzig: Brodhaus.

Suzuki, Sadami (2000). "From Canon Formation to Evaluational Reformulation: Man'yū, Genji, Bashō". PAJLS. Issue of Canonicity and Canon Formation in Japanese Literary Studies, 1, 25-45.

Treat, John Whittier (1993). "Yoshimoto Banana Writes Home: Shojo Culture and the Nostalgic Subject". The Society of Japanese Studies 19(2), 353-87.

Tachibana, Reiko, (1998). Narrative as Counter-Memory: A Half-Century of Postwar Writing in Germany and Japan. New York: State University of New York Press.

Tsubouchi Shōyō [1885] (2010). 小説神髄 Shōsetsu shinzui (The Essence of the Novel). Tōkyō: Watanabe Bunko. 
